\title{
Cikkismertetés: Live 5-2-1-0, azaz a gyermekkori elhízás megelőzése rendszerszintű gondolkodással és közösségek bevonásával
}

\author{
Article review: Live 5-2-1-0, that is the prevention of the childhood obesity \\ through systems thinking and community involvement
}

Ismertető: $\quad$ Prievara Dóra Katalin $\bowtie$

Szegedi Tudományegyetem, Juhász Gyula Pedagógusképző Kar,

Alkalmazott Egészségtudományi és Egészségfejlesztési Intézet

Ismertetett cikk: Amed S, Shea S, Pinkney S, Wharf Higgins J, Naylor P-J. Wayfinding the Live 5-2-1-0 initiative - At the intersection between systems thinking and community-based childhood obesity prevention. International Journal of Environmental Research and Public Health 2016; 13(614). doi:10.3390/ijerph13060614.

Beküldve: $\quad$ 2019. 08. 14.

doi: $\quad$ 10.24365/ef.v61i1.508

Kulcsszavak: gyermekkori elhízás; részvételi kutatás; egészségfejlesztés; közös eredményesség

Keywords: childhood obesity; participatory research; health promotion; collective impact

\section{HÁTTÉR}

A gyermekkori elhízás komplex probléma, melynek kezelése rendszertudományi szemléletet igényel. A következményei között szerepelnek az olyan krónikus megbetegedések, mint a 2-es típusú diabétesz, szívbetegségek és a rák kialakulása. A „Live 5-2-1-0" egy közösségeken alapuló intervenciós módszer, ami több szinten, többféle stratégia alkalmazásával, rendszertudományi szemléleten alapulva célozza meg a gyermekkori elhízás megelőzését az egyénitől a környezeti és a politikai szintekig. A kezdeményezés Brit Kolumbia közösségeivel közremúködve indult útjára. Ezek a közösségek motiváltak voltak olyan széleskörű programban való részvételre, amely a gyermekek és családjaik körében népszerüsíti és segíti az egészséges magatartásformák bevezetését.
A központilag kialakított program mellett figyelembe vették az adott közösségek specifikus jellemzőit is, mivel a kezdeményezés vezetői felvették a kapcsolatot helyi szakértőkkel (például a polgármesterekkel, egészségügyi szakemberekkel), segítve ezzel a legjobb eljárások gyakorlatba, a helyi viszonyokhoz alkalmazkodó átültetését. Ezt az adaptációt követően juthattak el az információk a közvetlen közönséghez, amelyet iskolák, tanárok, helyi média, lokális szervezetek és egészségügyi dolgozók alkottak, míg az üzenetek közvetett közönsége maguk a gyermekek és családjaik voltak.

\section{MÓDSZER}

Jelen vizsgálatban négy közösség vett részt, mely közül kettő már a „Live 5-2-1-0” kezdeményezés kidolgozásában is szerepet vállalt 2009 és 2012 
között, míg két közösség csak 2014 óta résztvevője a programnak. A bevont közösségek közül kettő nagyvárosban, egy-egy pedig városban, illetve vidéki kisvárosban található. A részt vevő közösségek különböző színterei között együttműködésre és kommunikációra volt szükség, amit a kutatás keretein belül központilag segítettek, ahogyan az információkat és segédanyagokat is mindenki számára online elérhetővé tették. Ez a segédlet különböző videókat, posztereket, hírleveleket, színes grafikákat és brosúrákat tartalmazott, marketingtervet és eszköztárat az egészséggel kapcsolatos üzenetek hatékony terjesztésére. A kutatók kevert típusú eljárást alkalmaztak, kvalitatív és kvantitatív adatokat egyaránt gyújtöttek interjúk, továbbá honlapok és kérdőívek elemzésével.

\section{EREDMÉNYEK}

\section{TANULSÁGOK A HAZAI SZAKEMBEREK SZÁMÁRA}

A gyermekkori elhízás összetett probléma, melyre átfogó megoldás kidolgozása szükséges. Ehhez elengedhetetlen, hogy a hazai szakemberek bevonják a lakosságot, ezen belül is a célcsoportot alkotó túlsúlyos gyermekeket és szúkebb környezetüket. A családnak ugyanis elsődleges szerepe van az életmódbeli szokások kialakításában, megváltoztatásában. A fenti témában érintett szakembereknek is érdemes lenne a közösségalapú rendszermegközelítés módszerét megismerni és alkalmazni a gyermekkori elhízás megelőzése érdekében.

A tanulmány szerzőinek célja az volt, hogy csökkentsék az információhiányt arra vonatkozóan, hogy a közösségek milyen fontos szerepet töltenek be az egészséges gyermekkori testsúly elérésében. Érzékennyé kell válni a csoportoktól jövő visszajelzésekre, az eddigi tapasztalatokat, módszereket pedig ennek fényében kell módosítani. A program jó példát mutat arra, hogy a hosszú távú és elkötelezett együttmúködés, a rendszerszintű szemlélet szükséges az olyan átfogó téma kezelésére, mint a gyermekek életvitele, melyet önmagában, a család nélkül nem is lehet módosítani. 